\title{
Hauterivian dinoflagellate cysts from Milne Land, East Greenland
}

\author{
STEFAN PIASECKI
}

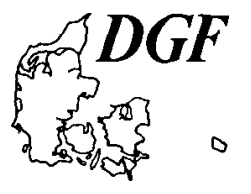

Piasecki, S.: Hauterivian dinoflagellate cysts from Milne Land, East Greenland. Bull. geol. Soc. Denmark, vol. 28, pp. 31-37, Copenhagen. October 23rd, 1979. https://doi.org/10.37570/bgsd-1979-28-06

A minor shaly sequence in the middle of the Hartz Fjeld Formation, Milne Land, central East Greenland is dated as Hauterivian on the basis its dinoflagellate cyst content. The assemblage is compared with the dinoflagellate stratigraphy of the Speeton Clay, England and the North Sea basin. This is the first report of Hauterivian sediments from East Greenland.

Stefan Piasecki, Institute of Historical Geology and Palaeontology, Oster Voldgade 10, DK-1350 København K, Danmark. April 24th, 1979.

During the summer of 1977 a party from Geological Survey of Greenland consisting of $T$. Birkelund, J. H. Callomon, F. Fürsich, C. Heinberg, L. Stemmerik and the author worked on the eastern part of Milne Land island in Scoresby Sund, East Greenland (fig. 1). One of the main intentions of the work was to compare a refined ammonite stratigraphy with a detailed record of dinoflagellate cysts. In addition, an attempt was made to date the youngest sediments on Milne Land, which had never before been dated due to a lack of diagnostic macrofossils; this is the subject of the present work.

In Milne Land 1100 metres of Jurassic - Cretaceous sediments directly overlie the crystalline basement. The sequence has mainly been described by Aldinger (1935), Spath $(1935,1936)$, Håkansson, Birkelund, Heinberg \& Willumsen (1971) and Sykes \& Brand (1976). The succession can be divided into three formations (Birkelund, Callomon \& Fürsich, 1978; Callomon \& Birkelund, in press), the oldest being the Charcot Bugt Formation, followed by the Kap Leslie Formation with the youngest being the Hartz Fjeld Formation. The coarse sediments of the basal Charcot Bugt Formation and the fine grained sediments of the overlying Kap Leslie Formation are well dated on the basis of ammonites as Upper Bathonian - Middle Volgian.

The Hartz Fjeld Formation (up to 300 metres thick) consists of a lower sandy unit, assignable in part to the Middle Volgian and the Upper Ryazanian - Lower Valangian on the basis of sparse ammonites. Above this are the undated sediments discussed here. These consist of a middle shaly unit, up to 30 metres thick, and an upper sandy unit approximately 100 metres thick. These two units are only present at Hartz Fjeld, having been removed by erosion in other areas.

The middle shaly unit was sampled in a clean and well exposed section, 20 metres thick, in northern Hartz Fjeld, and in a 27 metres thick, largely scree covered section in southern Hartz Fjeld. The lower sandy unit of the Hartz Fjeld Formation was not sampled.

Variation of assemblages.

All samples from the middle shaly unit and the upper sandy unit yielded pollen and spores, while dinoflagellate cysts were only found in the middle shaly unit: 5 samples out of 11 from this unit contained a rich dinoflagellate assemblage (fig. 2). Approximately 60 species were recognizable, though many occurred in low numbers. A rather haphazard distribution of the cysts in the sections gives the impression that many of the cysts may be reworked, but this could rarely be verified. The first occurrence of a species, in any case, has been regarded as the best criterium in dating these sediments, in order to exclude the problem of reworking. The content of dinoflagellate cysts in the middle shaly unit is variable; a rich assemblage was recovered from the lower part, whilst the middle part was barren of cysts. Rich assemblages were again recovered from the upper part. This helps to confirm the idea of a 


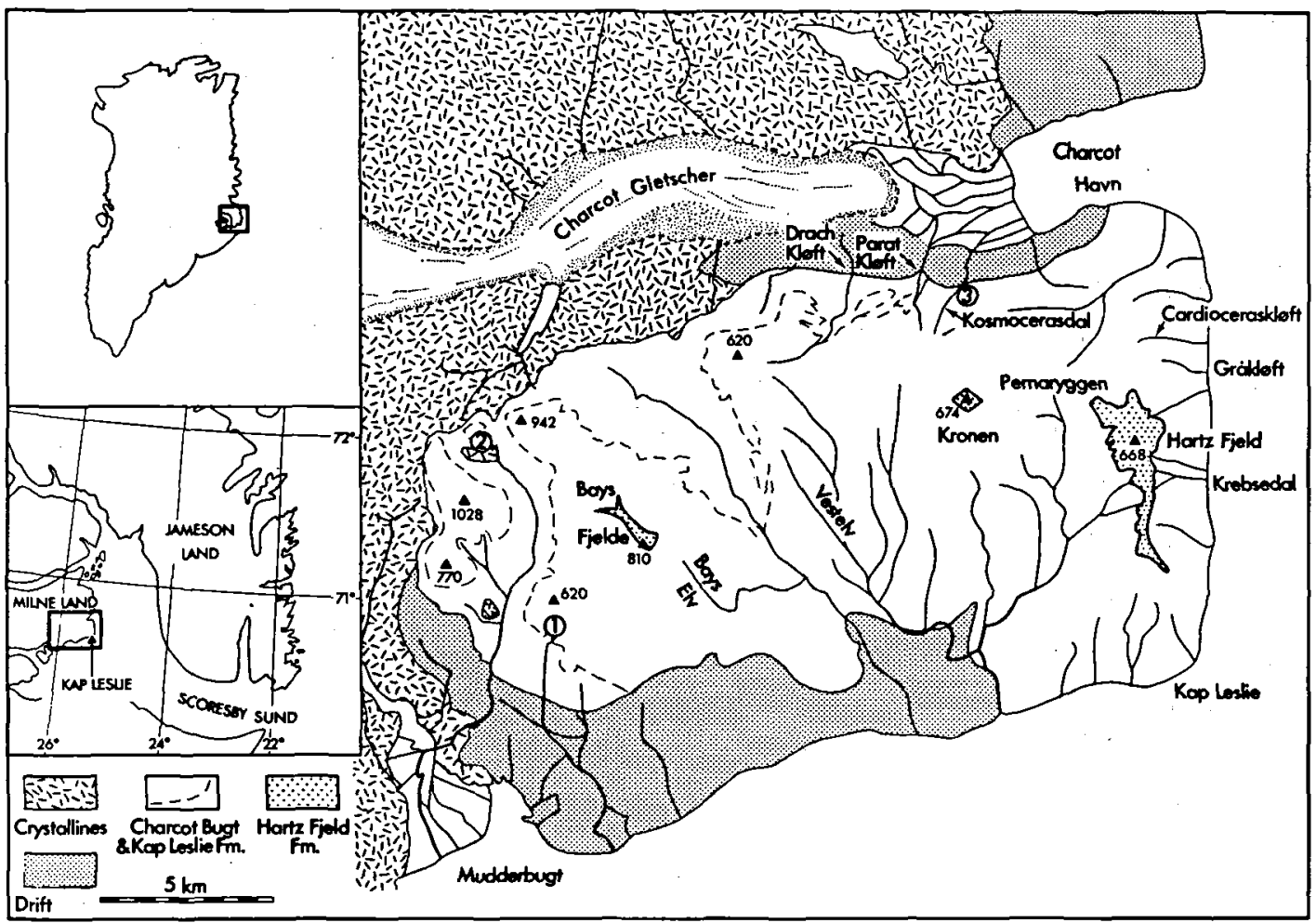

Fig. 1. Map of Milne Land, showing the distribution of Jurassic - Cretaceous sediments. After Callomon \& Birkelund (in press).

lagoonal environment with fluctuating marine influences during the deposition of this part of the sequence (Sykes \& Brand, 1976). Also the absence of dinoflagellate cysts in the carbonaceous horizons in the overlying upper sandy unit, together with abundant spores and pollen, confirms the idea of a nonmarine depositional environment for this part of the sequence (Sykes \& Brand, 1976).

\section{Stratigraphy.}

The dinoflagellate assemblage in the middle shale unit of the Hartz Fjeld Formation shows great affinity to that known from the English Speeton Clay and the North Sea. The Speeton Clay in England is well dated on the basis of ammonites and belemnites. Davey (1974) and Duxbury (1977) have described the stratigraphic distribution of dinoflagellate cysts from these sediments, and Davey (in press) has further established a detailed dinoflagellate stratigraphy for the North Sea area, based on selected species.
Several species with reported first occurrences in the Ryazanian and Valangian occur in the shale unit (fig. 3), and a few with a restricted range within this interval are also present. Because of the possibility of reworking these species are not regarded as indicating a Ryazanian Valangian age for the sediments.

The following species seem to be generally accepted as occurring in Hauterivian and younger strata: Discorsia nanna (Davey) Duxbury, 1977, Necrobroomea longicornuta (Alberti) Wiggins, 1975, Chlamydophorella trabeculosa (Gocht) Davey, in press and Systematophore schindewolfii (Alberti) Downie \& Sarjeant, 1964. S. schindewolfii is reported to occur in the uppermost Hauterivian, C 1 in the Speeton Clay (Duxbury, 1977), while Davey has found it only in Barremian and younger deposits (pers. comm.). $N$. longicornuta is common in the Barremian, but it is also found in the Hauterivian in low numbers. This may give the impression of a Barremian age for the shale, but no species which are restricted to Barremian have been found. 


\begin{tabular}{|c|c|c|c|c|c|}
\hline 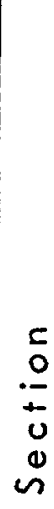 & 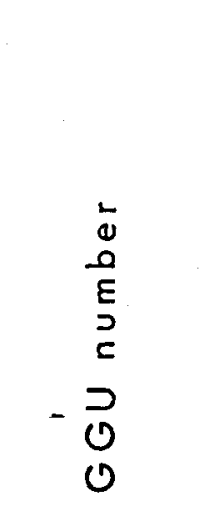 & \begin{tabular}{c}
$c$ \\
0 \\
\hdashline$\check{c}$ \\
0 \\
0 \\
$s$ \\
$w$ \\
0 \\
$n$ \\
$n$ \\
0 \\
$c$ \\
$\frac{c}{0}$ \\
$\frac{0}{c}$ \\
$\frac{1}{E}$
\end{tabular} & 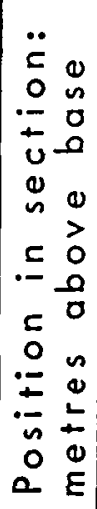 & $\begin{array}{l}0 \\
0 \\
0 \\
0 \\
0 \\
0 \\
0 \\
0 \\
0 \\
0 \\
0 \\
0 \\
0 \\
0\end{array}$ & 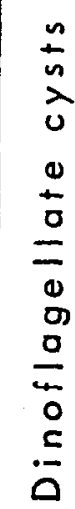 \\
\hline $\begin{array}{l}\Sigma \\
亡 \\
\vdots \\
Z\end{array}$ & $\begin{array}{ll}234 & 255 \\
234 & 254 \\
234 & 256 \\
234 & 257 \\
234 & 258\end{array}$ & 20 & $\begin{array}{r}12 \\
7 \\
2\end{array}$ & $x$ & $x$ \\
\hline $\begin{array}{l}\frac{1}{\hbar} \\
\vdots \\
0 \\
n\end{array}$ & $\begin{array}{ll}245 & 718 \\
245 & 719 \\
245 & 720 \\
245 & 721 \\
245 & 722 \\
245 & 723\end{array}$ & 27 & $\begin{array}{r}22 \\
17 \\
12 \\
7 \\
2 \\
0\end{array}$ & $x$ & $\begin{array}{l}X \\
X\end{array}$ \\
\hline
\end{tabular}

Fig. 2. The distribution and position of the samples in the sections.

There are significant disagreements between Davey and Duxbury about the first and last occurrence of several species. However, they agree about $N$. longicornuta having its first occurrece in $C 11$, Speeton Clay, and $C$. trabeculosa in C 9-C 11, equivalent to the upper Endemoceras beds, Lower Hauterivian. This is regarded as the main indication of an Hauterivian age for the shale from Milne Land, but several other species occurrences support the age.

Cribroperidinium sepimentum Neale \& Sarjeant, 1962 is present in low numbers, and Duxbury (1977) has reported a short range corresponding to the middle of the Hauterivian. It has also been reported from younger deposits
(Davey, 1974). Cleistosphaeridium polypes (Cookson \& Eisenack) Davey, 1969 is reported to have its first occurrence in the middle Hauterivian (Duxbury, 1977). Gonyaulacysta confossa Duxbury, 1977 is found only in one of the lower samples; it is reported to have a restricted range, C $4 b-$ LB 6 , in the Simbirskites beds of the Upper Hauterivian (Speeton Clay).

The presence of Necrobroomea jaegeri (Alberti) Wiggings, 1975 should indicate a late Hauterivian age or younger (Duxbury, 1977), but the difficulties in separating this species from Necrobroomea micropoda (Alberti) Wiggins, 1975 make this species less useful for stratigraphy. Rare specimens of Gonyaulacysta cretacea (Neale \& Sarjeant) Sarjeant, 1969, Gonyaulacysta helicoidea (Eisenack \& Cookson) Sarjeant, 1966 and Gonyaulacysta fastigiata Duxbury, 1977 support an Hauterivian age, but poor preservation makes specific identification difficult and therefore unsure.

Using only Davey's conclusions (in press) the shale would belong to the Discorsia nanna Zone, because of the presence of the zonal species, and the absence of Subtilisphaera terrula (Davey) Lentin \& Williams, 1975. More precisely, the shale would be referred to the Chlamydophorella trabeculosa Subzone, because of the presence of C. trabeculosa and the absence of $S$. terrula. Davey reports the first occurrence of Ctenidodinium elegantulum Millioud, 1969 and Endoscrinium campanulum (Gocht) Vozzhennikova, 1967 in this subzone, and both are present in the shale. In the overlying subzone (Canningia cf. reticulata Subzone) Muderongia simplex Alberti, 1961 and Chlamydophorella sp. A (Davey, in press) have their last occurrence, and they are also found in this shale unit.

The $C$. trabeculosa Subzone corresponds to the upper Endemoceras beds - lower Simbirskites beds (C $9-C 5)$ in the Speeton Clay, and is of partly early and partly late Hauterivian age. This age is slightly older than suggested initially due to the presence of $S$. schindewolfii and $G$. confossa, which are not used in Davey's stratigraphy. The occurrence of these two species make it resonable to regard the shale as being of late Hauterivian age. 


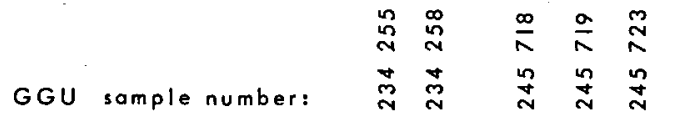

Previously Reported Range

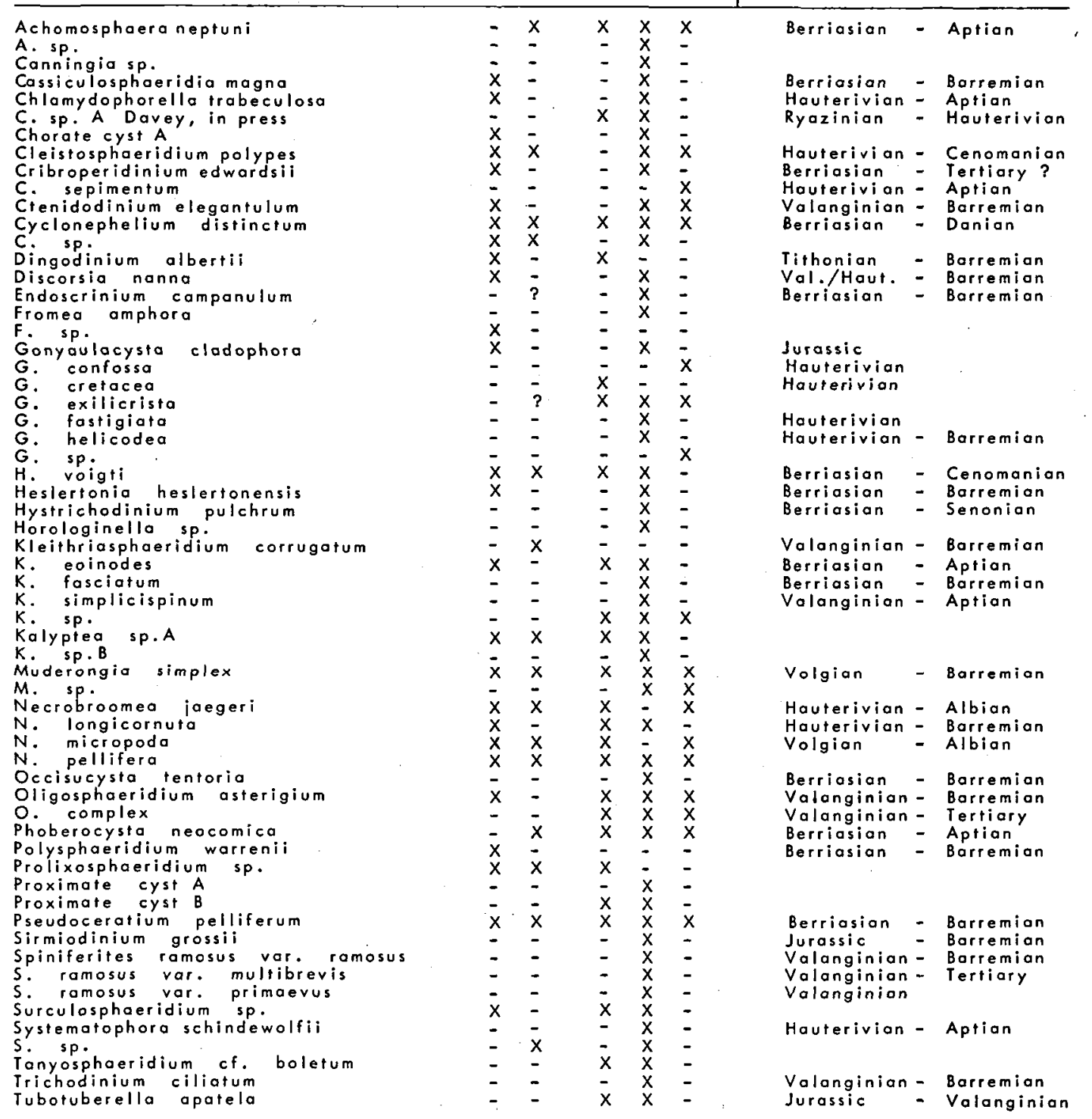

Fig. 3. List of species and their occurrences. The ranges are mainly based on data from Duxbury, 1977 and Davey (in press). 

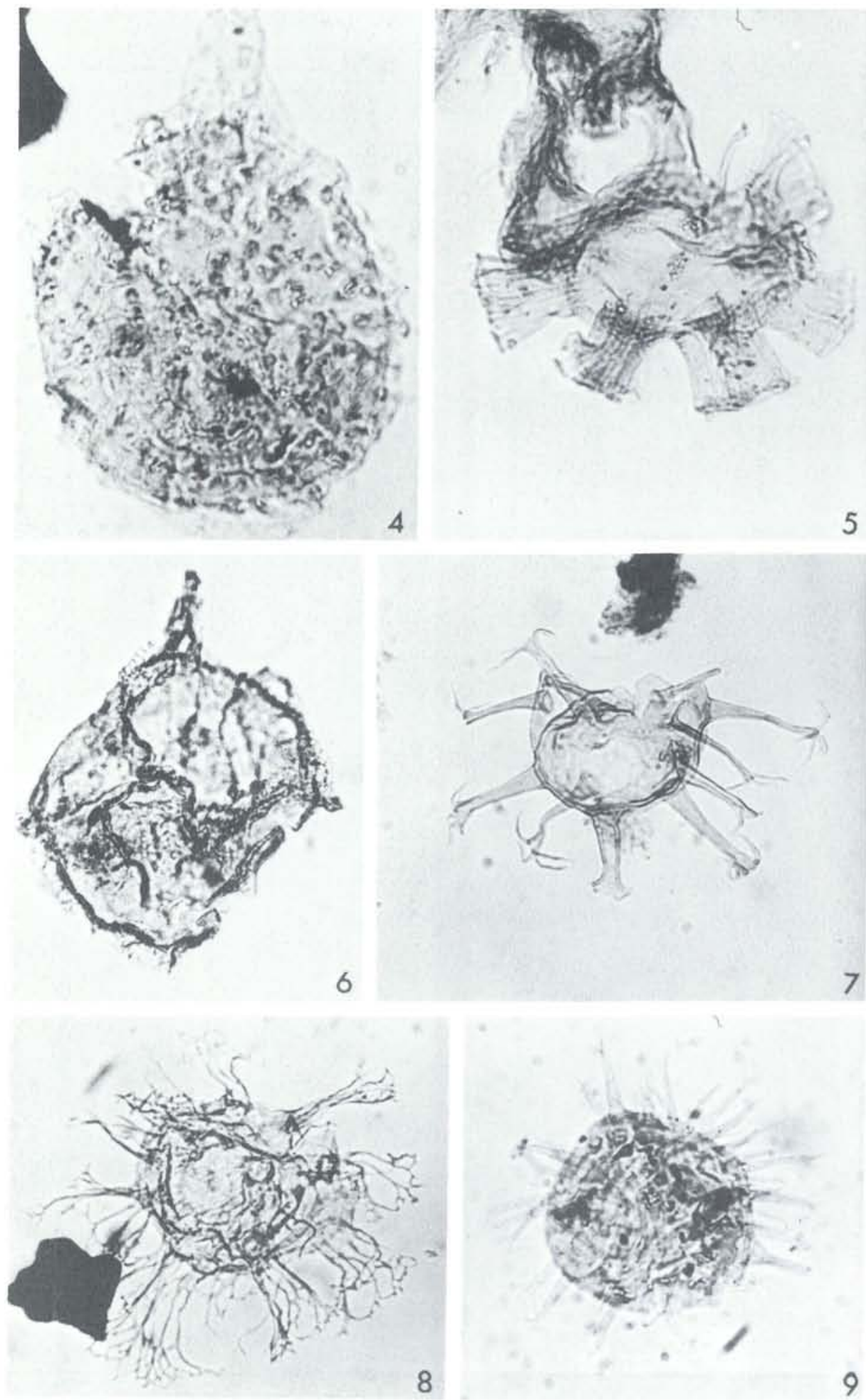

Fig. 4. Chlamydophorella trabeculosa $1000 X$, GGU 245719. Fig. 5. Discorsia nanna $1000 X, G G U 245719$.

Fig. 6. Cribroperidinium sepimentum 500 X, GGU 245723.
Fig. 7. Oligosphaeridium asterigium $500 X$, GGU 245723. Fig. 8. Systematophora schindewolfii $500 X, G G U 245719$. Fig. 9. Cleistosphaeridium polypes 1000 X, GGU 245719. 
Piasecki: Hauterivian dinoflagellates
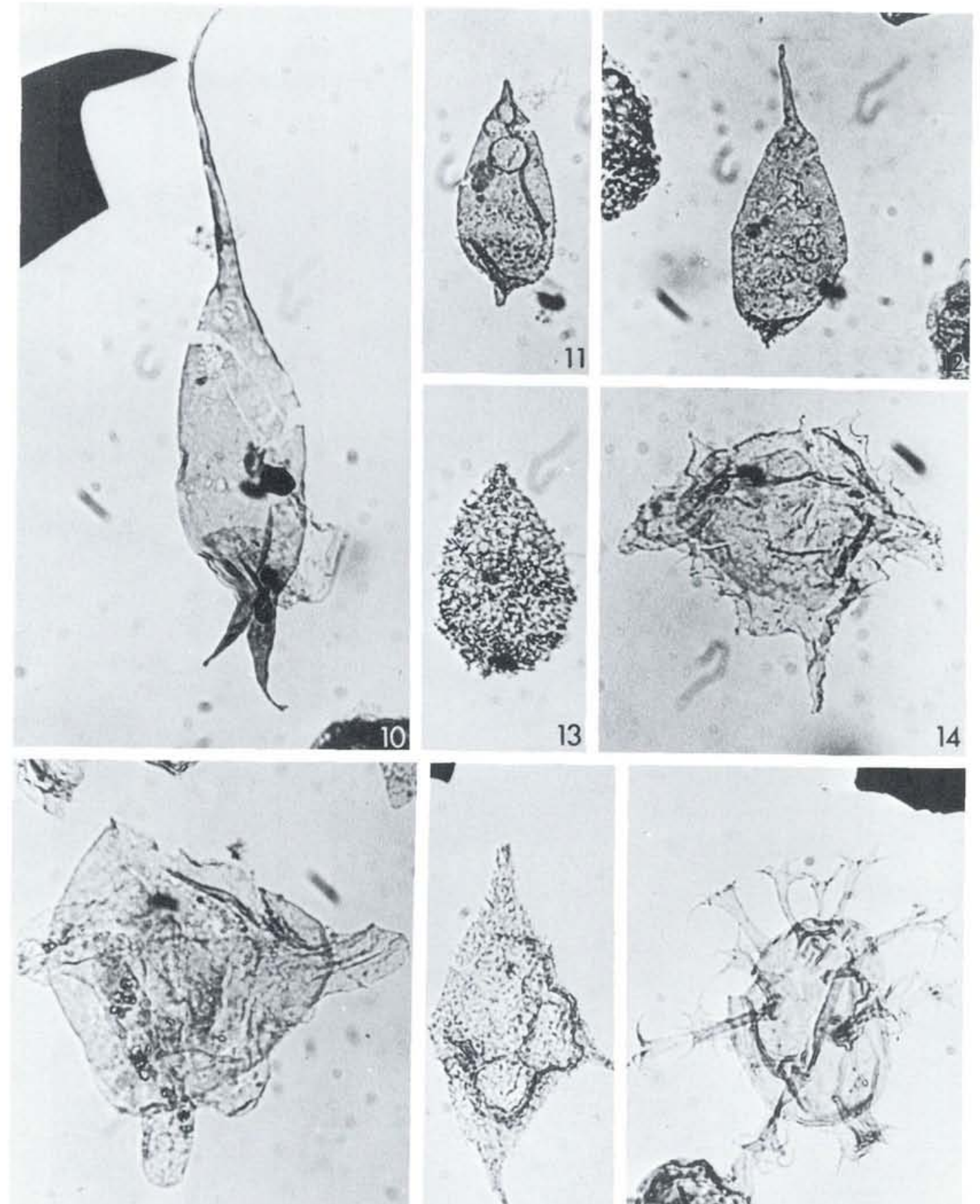

15

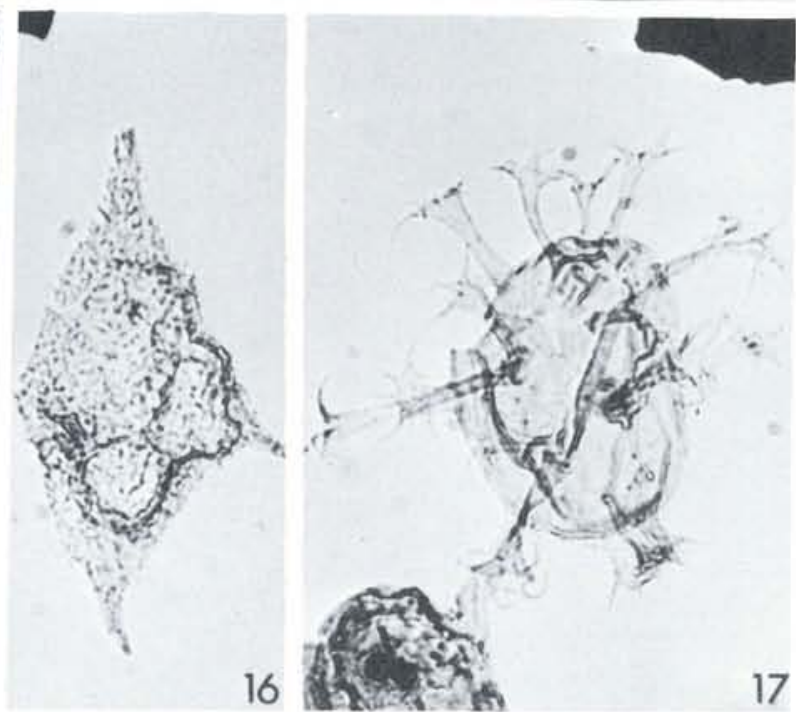

Fig. 10. Necrobroomea longicornuta $500 X$, GGU 234255. Fig. 11. Necrobroomea micropoda $500 X$, GGU 245723. Fig. 12. Necrobroomea jaegeri $500 X$, GGU 234255. Fig. 13. Necrobroomea pellifera $500 X, G G U 234255$.
Fig. 14. Phoberocysta neocomica $500 X$, GGU 245718. Fig. 15. Muderongia simplex $500 X$, GGU 245723.

Fig. 16. Pseudoceratium pelliferum 500 X, GGU 245719. Fig. 17. Oligosphaeridium complex 500 X, GGU 245719. 


\section{Conclusions}

The dinoflagellate cysts in the middle shale unit of the Hartz Fjeld Formation are mainly long ranging species. A certain number of the species indicate an Hauterivian age $(C$. trabeculosa, $D$. nanna, $N$. longicornuta and others), while a few species are confined to the Upper Hauterivian ( $S$. schindewolfii and $G$. confossa).

Sediments of Valangian and Aptian age are present at several localities in East Greenland from Scoresby Sund to Store Koldewey (Birkelund \& Perch-Nielsen, 1976), while Hauterivian and Barremian sediments have not previously been reported from this area. The presence of Hauterivian sediments on Milne Land is thus the first documentation of sediments from this time interval in East Greenland.

Acknowledgements. The work was supported by grant from the Danish Natural Science Research Foundation. The paper is published with the permission of the Director of the Geological Survey of Greenland. H. Egelund made the drawings and Dr. J. S. Peel and Dr. R. J. Davey improved the English text.

\section{Dansk sammendrag.}

I et indtil 30 meter tykt skifer indslag i Hartz Fjeld Formationen på Milne Land, Øst Grønland, er der fundet dinoflagellat cyster, mens resten af formationen kun indeholder pollen og sporer. Der er stor lighed med tidligere beskrevne dinoflagellat floraer fra Speeton Clay i England og fra boringer i Nordseen. Skifer laget kan dateres til at være af Hauterivian alder. Der er ikke tidligere fundet sedimenter af denne alder i Øst Grønland.

\section{References}

Aldinger, H. 1935: Geologische Beobachtungen im oberen Jura des Scoresbysundes (Ostgrönland). Meddr Gronl. 99(1): $128 \mathrm{pp}$.

Alberti, G. 1961: Zur Kenntnis mesozoischer und alttertiärer Dinoflagellaten und Hystrichosphaerideen von Nord- und Mitteldeutschland sowie einigen anderen europäischen Gebieten. Palaeontographica, Abt. A, 116: 1-58.

Birkelund, T., Callomon, J. H. \& Fürsich, F. T. 1978: The Jurassic of Milne Land, central East Greenland. Rapp. Gronlands geol. Unders. 90: 99-106.

Birkelund, T. and Perch-Nielsen, K. 1976: Late Palaeozoic Mesozoic evolution of central East Greenland. In: Esher, A. \& Watt, W. S. (eds.). Geology of Greenland 305-339. Copenhagen: Geological Survey of Greenland.
Callomon, J. H. and Birkelund, T. in press: The Jurassic transgression in Milne Land, central East Greenland. Geol. Mag.

Davey, R. J. 1969: Non-calcareous Microplankton from the Cenomanian of England, northern France and North America, Part 1. Bull. Brit. Mus. (Nat. Hist.), Geol,, 17: 103-180.

Davey, R. J. 1974: Dinoflagellate Cysts from the Barremian of the Speeton Clay, England. Birbal Sahni Inst. of Paleobotany, Special Publication 3: 41-75.

Davey, R. J. in press: The stratigraphic distribution of dinocysts in the Portlandian (Latest Jurassic) to Barremian (Early Cretaceous) of Northwest Europe. Amer. Assoc. Strat. Palynol., Contrib. Ser.

Downie, C. and Sarjeant, W. A. S. 1964: Bibliography and Index of Fossil Dinoflagellates and Acritarchs. Geol. Soc. Amer. Mem., 94: 180 pp.

Duxbury, S. 1977: A Palynostratigraphy of the Berriasian to Barremian of the Speeton Clay of Speeton, England. Palaeontographica, Abt. B, 160: 17-67.

Eisenack, A. \& Cookson, I. C. 1960: Microplankton from Australian Lower Cretaceous Sediments. Proc. Roy. Soc. Victoria, 72: 1-11.

Gocht, H. 1959: Mikroplankton aus dem nordwestdeutschen Neokom (Teil II). Paläontol. Z., 33: 50-89.

Håkansson, E., Birkelund, T., Heinberg, $C$. and Willumsen, P. 1971: Preliminary Results of Mapping the Upper Jurassic and Lower Cretaceous Sediments of Milne Land. Rapp. Gronl. geol. Unders. 37: 32-41.

Lentin, J. K. and Williams, G. L. 1975: A Monograph of Fossil Peridinoid Dinoflagellate Cysts. Bedford Institute Oceanography, Rept. BI-R-75-16: 237 pp.

Millioud, M. E. 1969: Dinoflagellates and Acritarchs from some western European Lower Cretaceous type localities. In Brönniman, P. \& Renz, H. H.: Proceedings First International Conference Planktonic Microfossils, Geneva 1967, 2: 420-434.

Neale, J. W. and Sarjeant, W. A. S. 1962: Microplankton from the Speeton Clay of Yorkshire. Geol. Mag. 99: 439-458.

Sarjeant, W. A. S. 1966: Dinoflagellate Cysts with Gonyaulax-type tabulation. In Davey, R. J., Downie, C., Sarjeant, W. A. S. and Williams, G. L.: Studies on Mesozoic and Cainozoic Dinoflagellate Cysts. Bull. Brit. Mus. (Nat. Hist.), Geol., Supplement 3: 107-156.

Sarjeant, W. A. S. 1969: Taxonomic changes. In Davey, R. J., Downic, C., Sarjeant, W. A. S. and Williams, G. L.: Appendix to $>$ Studies on Mesozoic and Cainozoic Dinoflagellate Cysts\&. Bull. Brit. Mus. (Nat. Hist.), Geol., Appendix to Supplement 3: 7-15.

Spath, L. F. 1935: The Upper Jurassic invertebrate faunas of Cape Leslie, Milne Land. I. Oxfordian and Lower Kimmeridgian. Meddr Gronl. 99(2): 82 pp.

Spath, L. F. 1936: The Upper Jurassic invertebrate faunas of Kap Leslie. II. Upper Kimmeridgian and Portlandian. Meddr Gronl. 99(3): 180 pp.

Sykes, R. M. and Brand, R. P. 1976: Fan delta sedimentation: an example from the late Jurassic - early Cretaceous of Milne Land, central East Greenland. Geol. Mijnb. 55: 195-203.

Vozzhennikova, T. F. 1967: Iskopaemye peridinei jurskich melovych i paleogenovych otloženij SSSR. Akad. Nauk. SSSR, Sib, Otd., Inst. Geol. Geofiz., Tr.: 347 pp.

Wiggins, V. D. 1975: The dinoflagellate family Pareodiniaceae: discussion. Geoscience and Man 11: 95-115. 